\begin{tabular}{|c|c|c|c|c|c|}
\hline 判 定 & (卅) & (H) & $(+)$ & $(-)$ & Total \\
\hline 症 例 & 6 & 5 & 3 & 3 & 17 \\
\hline$\%$ & 35.4 & 29.4 & 17.6 & 17.6 & 100.0 \\
\hline
\end{tabular}

\section{第 3 表}

\begin{tabular}{|c|c|c|c|c|c|c|}
\hline \multicolumn{3}{|c|}{ 発病より治療開始まで 判定 州 } & H & + & - & 計 \\
\hline \multicolumn{2}{|c|}{24 時間以内 } & 5 & 2 & & & 7 \\
\hline 2 & 日 & & 2 & & 1 & 3 \\
\hline 3 & 日 & & & 2 & & 2 \\
\hline 4 & 日 & & 1 & & & 1 \\
\hline 5 & 日 & 1 & & & & 1 \\
\hline 2 & 週 & & & 1 & 1 & 2 \\
\hline 2 & ケ 月 & & & & 1 & 1 \\
\hline & 計 & 6 & 5 & 3 & 3 & 17 \\
\hline
\end{tabular}

覚的には発赤, 腫脹が見られるが，化膿性炎症像は殆 んぞ見られない時期である. 此の時期は抗とスタミ゙ン 凨と，ズ剤抗生剂の両者共効果の不充分な時期で放置 すると $4 \sim 5$ 日は上気道の不快感が続く時期であり私 の考えている次の第 3 期の副鼻洞, 中耳, 咽頭扁桃, 気管支等の化膿性炎症に移行する時期である，特に下 咽頭より喉頭の症状に対しては, 薬物療法では極め手 がなく，安静と早期就床が最良の治療であるとも言わ れ，予防の為に化学剤の投与が行われるが，現症を積 瑶的に治瘑に赴かしむる様な対策は従来はとられず，
マンデル氏液の塗布，含嫩，吸入等が耳科医としての 治療であつた。しかし実際には就床するには病勢は軽 く, 解熱剤を含む所謂風邪菒, 抗七スタミン剤等は効 果はうすく，且つ抗生物質，スルフアミン剂等の投与 には尚早の時期で，虫者は不快感があるにも抱らず， 就業している為に能率の低下は否定出来ない。

此の時期に著者らは, 従来も行われていた慣例の吸 入剂に代えて，抗ヒスタミン剤，副腎皮質ホルモン， 抗生物質をもつてし，積極的に上気道の消炎をはかり 早期に治療せしめんとの意図で，近年各種の薬剤の上 気道噴霧療法を試みて来たが，中耳，外耳の炎症に耳 科用プレデックス液の効果が予想以上であつた事にヒ ントを得て，これを上気道炎症に用いて上述の如き効 果をみたものである.

惟うに本薬夜の上気道噴霧には，その使厓時期が最 も大切なものの如くで，放置すれば 1 週以上，時には 1 月以上も咳嫩，喀痰，嗄声等に悩まされる経過の途 中で，タイミングよくこれを頓挫せしめ得る事は，此 の種の薬液の新しい使用法として推賞に值するものと 思う，けだしフラジオマイシンも全身投与には比較的 副作用が強い為外用にのみ用いられるが，粘膜よりの 吸収も少く，粘膜表層の感染には効果が大で，プレド ニゾロンの消炎作用と相俟つて比較的広範囲な上気道 感染症のある時期に噴霧療法として用いる事は極めて 効果的である事がわかつたので，御追試をるがい報告 した次第である.

\title{
咽喉頭神経症と Sucrets口内錠療法
}

\section{鰕原 勇・藤森克男・鈴木達児・辻 茂久・橋本喜光*}

\section{1..はじめに}

咽喉頭部局所の異物感又は異常感，乾燥感，閉塞感にはじまつて，頸部緊張感，肩こり，頸・胸・ 頭部への放散性鈍痛まで訴えて来院する患者のなかには，治療によつて容易に主訴の消褪しないも のがおり，日常臨床家にとつて咽喉頭神経症の患者の処置には手を焼く場合もある.

これ迄咽喉頭神経症の原因 ${ }^{1-3 \oplus)}$ としてあげられてきた疾患としては，舌根扁桃肥大，会妝軟骨異 常, 甲状軟骨化骨異常, 過長茎状突起症, 慢性限局性浮腫性食道炎, 頸椎異常, 慢性扁桃炎, 鼻咽 腔炎，貪血，血清鉄の低下，慢性胃炎，腸内寄生虫，等の他，性ホルモン異常，自律神経異常にい

$*$ 東京医科歯科大学耳鼻咽喉科学教室 (主任 : 堀口申作教授) 
たる迄非常に多い，又神経症患者の性格として内向性素因，環境因子等の相互作用等が論ぜられて いる。

しかしながら実地臨床においては，上述の諸因子を一つ一つ考虑しなくともすむ場合も多く簡単 な治療処置で, 思わぬ効果を期待できることも少くないようである. 今回著者は日本メルク万有K.K より Sucrets口内錠の試用の機会を得，本来本剮は医薬品として使用されてきたものでなかつたが， 咽喉頭部の異物感乾燥感を主として治療をうけていた患者に使用し好結果をえたので Sucrets 口内 錠の紹介をかねて報告する。

\section{Sucrets 口内 錠}

本剤は一錠中へキシールレゾルシン (Hexylresorcin ol） $2.4 \mathrm{mg}$ 含有を主成分とする嘴好品でその組成は下 記の如きものである.

1) Hexylresorcinol 構造式

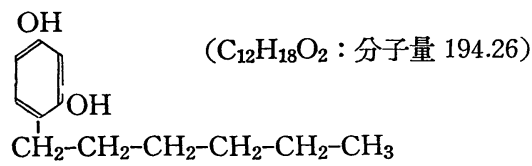

2) Sucrets 口内錠（1 錠中）

Hexylresorcinol $\cdots \cdots \cdots \cdots \cdots \cdots \cdots \cdot 2.4 \mathrm{mg}$
$\left.\begin{array}{l}\text { Pepermint } \\ \text { Mentol }\end{array}\right\} \cdots \cdots \cdots \cdots \cdots \cdots \cdots \cdots \cdots$
微 量
泉 葡糖

味は Pepermint drop 々類似し，带淡緑色で，風雅 な外観を呈している．正常人12名に一錠宛試用させた 結果は第 1 表の如くであり. Pepermint 独自の味覚が 人により好き，嫌いの判断をひきおこしている様に思 われた．試用後の感想の主なものは舌のシビレ感と試 用直後の味覚鈍麻で，その持続時間は平均 1 時間以内 の場合が大部分で，そのほか試用者のなかには口腔内 の清凉感を訴える人もみられたが，正常人の試用結果 では，シビレ慮と清凉感が，効果の上では相殺されて いた。

\section{3. 投与方法および投与対象}

Sucrets 口内錠の投与方法は 1 日 4 錠一率とし，いず れも食間に使用させた。投与の対象は咽喉頭神経症状 を主訴とする外来患者で, 対象はいずれも舌根扁桃肥 大, 喉頭蓋軟骨異常, 過長茎状突起症, 頸椎異常等の
疑いのない疾患を有する患者だけに使用し，単純な鼻 咽喉頭処置以外の治療は殆んぞ同時には使用しなかつ た.

表 1 正常人の試用成 績

\begin{tabular}{|c|c|c|c|c|c|c|c|c|c|}
\hline 症例数 & 姓 & 名 & 年 令 & 性 & 味 & シビレ感 & 持続時間 & 副 作 用 & \\
\hline No. 1 & & & 28才 & 古 & 良 & $(-)$ & 30 分 & $(-)$ & 清 涼感 \\
\hline 2 & & & 28才 & 古 & 良 & $(t)$ & 1 時 間 & 味覚障害 & 清 涼 感 \\
\hline 3 & & & 34才 & 古 & 良 & $(+)$ & 1 時間 & 同 & \\
\hline 4 & & & 33才 & 古 & 不快 & $(t)$ & 2 時 間 & 同 & 清 涼 感 \\
\hline 5 & & & 32 才 & 우 & 良 & $(+)$ & 1 時 間 & 同 & \\
\hline 6 & & & 23才 & 우 & 良 & $(+)$ & 1 時 間 & 同 & \\
\hline 7 & & & 24才 & 우 & 不快 & $?$ & 不 明 & 不 & \\
\hline 8 & & & 20才 & 우 & 不快 & $?$ & 不 明 & 不 明 & \\
\hline 9 & & & 32 才 & 古 & 良 & $(-)$ & $(-)$ & 味覚障害 & \\
\hline 10 & & & 18才 & 우 & 良 & $(+)$ & 1 時 間 & 同 & 清 涼 感 \\
\hline 11 & & & 36 才 & 古 & 良 & $(t)$ & 1 時 間 & 同上 & \\
\hline 12 & & & 26才 & 占 & 良 & $(t)$ & 30 分 & 味覚障害 & 清 涼 感 \\
\hline
\end{tabular}

$10-24$ 


\section{4. 効果 の 判 定}

効果の判定は Sucrets 口内錠投与量が20錠に達する 以内で行ない，視診所見は判定の規準から除外し，す べて来院時主訴の自覚症状の経過だけを問沴して，自 覚症状の軽減した場合を有効，消失した場合を著効又 は治瘜とし，それ以外の場合はすべて無効と判定して 附表した。

Sucrets 口内錠の使用効果を系統的に 観察するため に投与対象 32 例を 3 群にわけ，第 1 群は明かに器質的 炎症所見を有する急性疾患群, 第 2 群は主訴発現以来 6 ケ月以上経過し，且つ15日以上治療をうけて主訴の 消䘽しなかつた慢性疾患群，第 3 群は，第 2 群と同じ 臨床経過を有し且つ明かに他の慢性疾患を合併する咽 喉頭神経症群とした。

\section{5. 投与成績およびその検討}

投与対象を 1 群 (急性炎症性疾患)， 2 群 (慢性咽喉 頭神経症群)， 3 群 (慢性疾患合併症群）と分けて，そ の成績を表示すると〔表 2 〕〔表 3 〕，〔表4〕のごと くになる.

〔表 2〕，〔表 3〕，〔表4]を総括して，項目別に検討 してみると次のような特徴的効果が観察される.

\section{a. 有効症状 :}

自覚症のなかで Sucrets 製剤の有効な症状は投与対 象数32例のうちの有効症例16例（50\%）のなかで，咽 喉頭異物感（又は異常感） 9 例 (56\%), 閉塞感, 腫 脹感各 2 例, 咽頭痛 2 例, 違和慮 1 例の順であつた。 この異物感への奏勃機序は恐らく[表 1]の実験結果か ら明かなように， Sucrets 口内錠の有効成分である. Hexylresorcinol による口腔, 咽搌頭部粘莫の知覚鈍麻 作用にもとづくと考えてよいように思われる.

閉塞虑・腫脹感 - 咽頭痛違和感についても, 同様知 覚鈍麻作用にも基因するが，Hexylresorcinol 自体に殺 菌力もあり，消化器系の異常醴酵の抑制機序もあるこ とが既に薬理学的にも明かなところを考虑すればここ れらの薬理作用の相互作用もあら゙かつて効あるもので あるという考えを否定できないと思う。

有効症例数は投与対象群により，相当な差異が見ら れる. すなわち第 1 群の急性炎症群では Sucrets 口内 錠の単独投与では 8 例中,わずか 1 例の有効例であり， 第 2 群の炎症所見のすくない，慢性の神経症状を訴え る群で19例中13例（69\%）に有効例をみた。第 3 群の 明かに慢性疾患を合併し，その慢性疾患に随伴した神 経症状群では 5 例中有效例を 1 例もみていない。この ような差異の生ずる理由は， Sucrets 口内銫に著明な

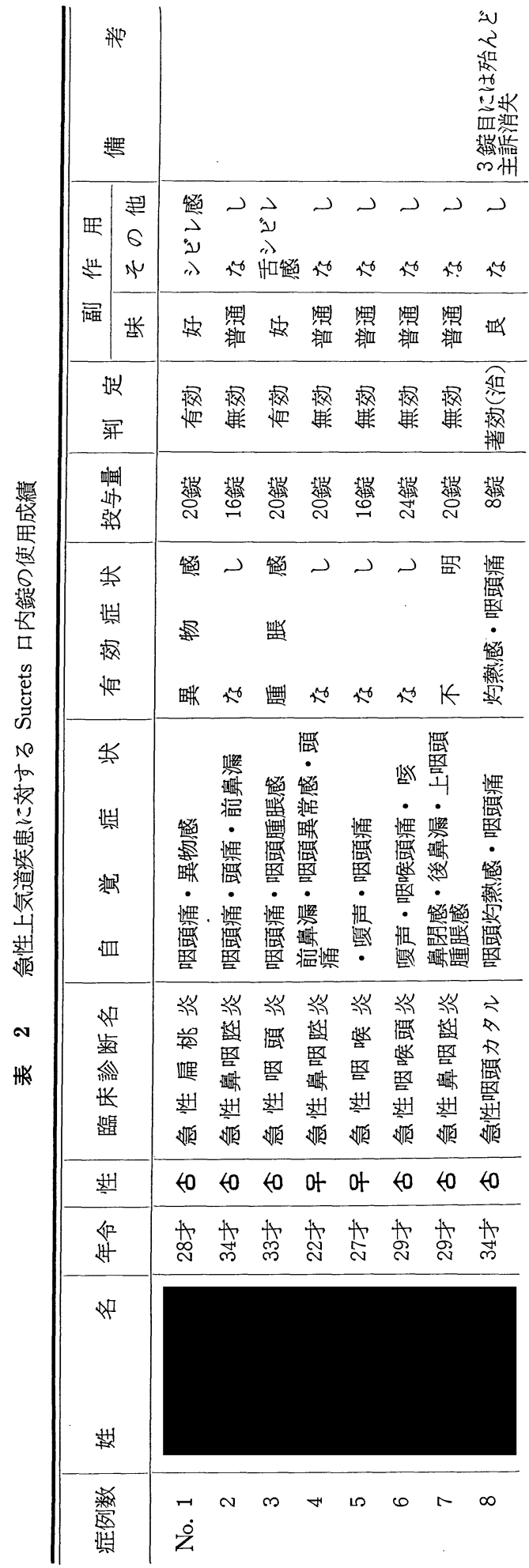




\begin{tabular}{|c|c|c|c|c|c|c|c|c|c|c|c|c|c|c|c|c|c|c|c|}
\hline 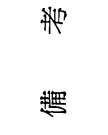 & \multicolumn{5}{|c|}{ 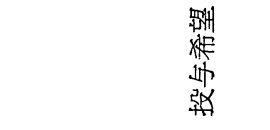 } & & & & & & 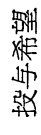 & & 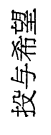 & $\begin{array}{l}4 \\
\text { 四 }\end{array}$ & $\begin{array}{l}4 \\
\text { 區 }\end{array}$ & $\begin{array}{l}11 \\
\text { 區 }\end{array}$ & & & $\begin{array}{l}41 \\
7\end{array}$ \\
\hline \multirow{2}{*}{ 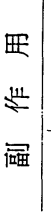 } & 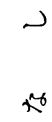 & 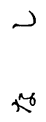 & 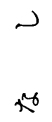 & 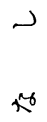 & \lrcorner & 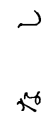 & 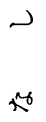 & $\begin{array}{l}\sim \\
x \\
x\end{array}$ & 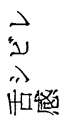 & D & 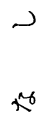 & م & 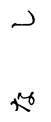 & 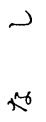 & 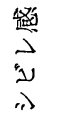 & 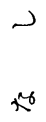 & 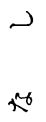 & 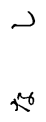 & 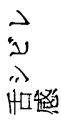 \\
\hline & $\begin{array}{l}\text { 抽 } \\
\text { 岕 }\end{array}$ & $\frac{E}{k}$ & 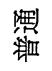 & $\begin{array}{l}\text { tu } \\
\text { 出 }\end{array}$ & 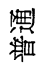 & 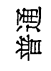 & $\begin{array}{l}\text { Hu } \\
\text { 出 }\end{array}$ & 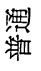 & $\begin{array}{l}\text { Hu } \\
\text { 嵓 }\end{array}$ & 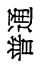 & $\begin{array}{l}\text { tu } \\
\text { 出 }\end{array}$ & $\begin{array}{l}\text { Hu } \\
\text { 出 }\end{array}$ & $\begin{array}{l}\text { to } \\
\text { 必 }\end{array}$ & $\begin{array}{l}\text { thu } \\
\text { 染 }\end{array}$ & $\begin{array}{l}\text { 拀 } \\
\text { 究 }\end{array}$ & 故 & $\begin{array}{l}\text { 枚 } \\
\text { 出 }\end{array}$ & 枚 & $\begin{array}{l}\text { 無 } \\
\text { 流 }\end{array}$ \\
\hline $\begin{array}{l}\text { 㸛 } \\
\text { 腺 }\end{array}$ & $\begin{array}{l}\text { 䨗 } \\
\text { 监 }\end{array}$ & $\begin{array}{l}\text { 雬 } \\
\text { 箱 }\end{array}$ & $\begin{array}{l}\text { 霜 } \\
\text { 他 }\end{array}$ & $\begin{array}{l}\text { 雨 } \\
\text { 监 }\end{array}$ & 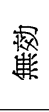 & 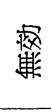 & 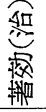 & 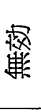 & $\begin{array}{l}\text { 䨗 } \\
\text { 监 }\end{array}$ & 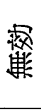 & $\begin{array}{l}\text { 雬 } \\
\text { 监 }\end{array}$ & $\begin{array}{l}\text { 䨗 } \\
\text { 巡 }\end{array}$ & $\begin{array}{l}\text { 雬 } \\
\text { 监 }\end{array}$ & $\begin{array}{l}\text { 䨗 } \\
\text { 监 }\end{array}$ & $\begin{array}{l}\text { 柋 } \\
\text { 霜 } \\
\text { 湘 }\end{array}$ & $\begin{array}{l}\text { 雨 } \\
\text { 监 }\end{array}$ & 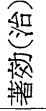 & $\begin{array}{l}\text { 䨗 } \\
\text { 监 }\end{array}$ & $\begin{array}{l}\text { 雬 } \\
\text { 翡 }\end{array}$ \\
\hline 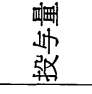 & $\begin{array}{l}\text { 策 } \\
\text { 今 }\end{array}$ & 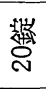 & $\begin{array}{l}\text { 遇 } \\
\text { 足 }\end{array}$ & 签 & 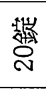 & 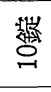 & 签 & 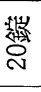 & 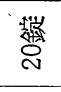 & 管誉 & 签 & $\begin{array}{l}\text { 榉 } \\
\text { Oे }\end{array}$ & 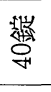 & 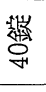 & 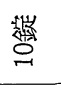 & $\begin{array}{l}\text { 谈 } \\
\text { 并 }\end{array}$ & $\begin{array}{l}\text { 啮 } \\
\text { 品 }\end{array}$ & 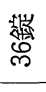 & 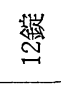 \\
\hline 出 & 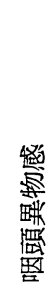 & $\begin{array}{l}-\infty \\
x \\
x\end{array}$ & 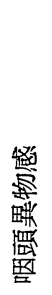 & 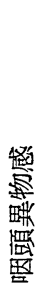 & $\begin{array}{l}\text { 監 } \\
k\end{array}$ & $\begin{array}{l}\text { 监 } \\
K \\
K\end{array}$ & 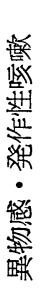 & $\begin{array}{l}\text { 監 } \\
K\end{array}$ & 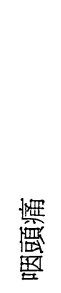 & $\begin{array}{l}\text { 䁅 } \\
K\end{array}$ & 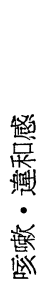 & 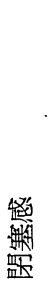 & 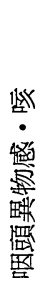 & 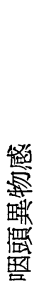 & 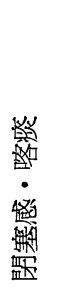 & 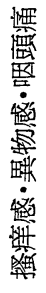 & 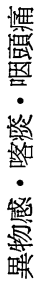 & 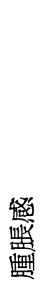 & $\begin{array}{l}\text { 监 } \\
K\end{array}$ \\
\hline 4 & 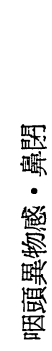 & 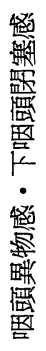 & 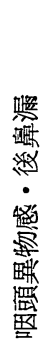 & 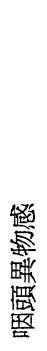 & 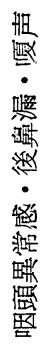 & 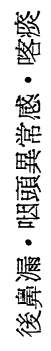 & 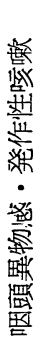 & 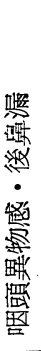 & 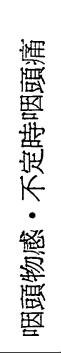 & 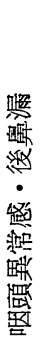 & 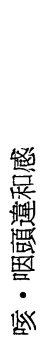 & 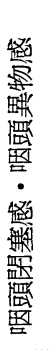 & 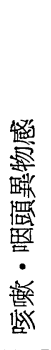 & 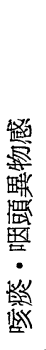 & 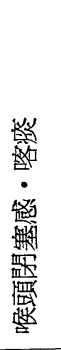 & 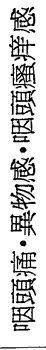 & 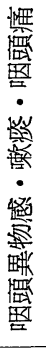 & 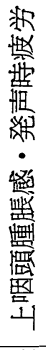 & 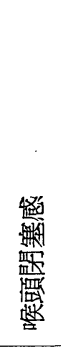 \\
\hline 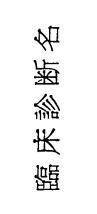 & 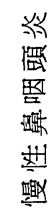 & 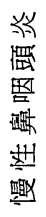 & 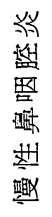 & 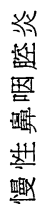 & 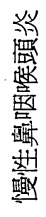 & 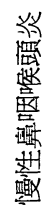 & 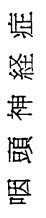 & 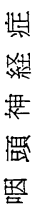 & 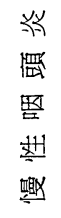 & 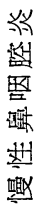 & 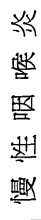 & 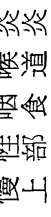 & 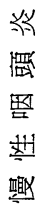 & 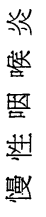 & 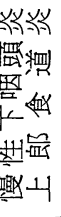 & 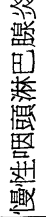 & 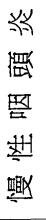 & 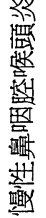 & 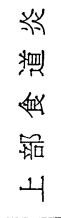 \\
\hline 世聂 & 40 & to & to & to & to & to & 아 & 아 & to. & 아 & 아 & 아 & 아 & to & 아 & 아 & to & 아 & 아 \\
\hline $\begin{array}{l}\text { 迎 } \\
\text { से }\end{array}$ & $\begin{array}{l}\text { W } \\
\infty \\
0\end{array}$ & 상 & 㐫 & $\underset{\substack{n \\
\text { N }}}{\pi}$ & $\underset{\infty}{\mathbb{N}}$ & 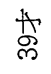 & 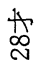 & 血 & $\underset{m}{\mathbb{m}}$ & 出 & 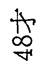 & 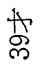 & 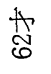 & $\underset{\forall}{\stackrel{\Im}{*}}$ & $\underset{+}{+}$ & 屯্ & 芯 & 志 & $\underset{\forall}{\stackrel{+}{\rightleftarrows}}$ \\
\hline \multicolumn{20}{|l|}{$\$ 7$} \\
\hline \multicolumn{20}{|l|}{$\underset{*}{*}$} \\
\hline 雬 & $\stackrel{-1}{\dot{Z}}$ & $N$ & $m$ & $\not$ & 10 & 6 & $N$ & $\infty$ & $\sigma$ & 으 & $\Rightarrow$ & $\stackrel{\sim}{\sim}$ & $\stackrel{m}{\rightarrow}$ & 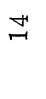 & $\stackrel{10}{\sim}$ & $\stackrel{\bullet}{-1}$ & $\simeq$ & $\stackrel{\infty}{\sim}$ & $\stackrel{\infty}{-1}$ \\
\hline
\end{tabular}




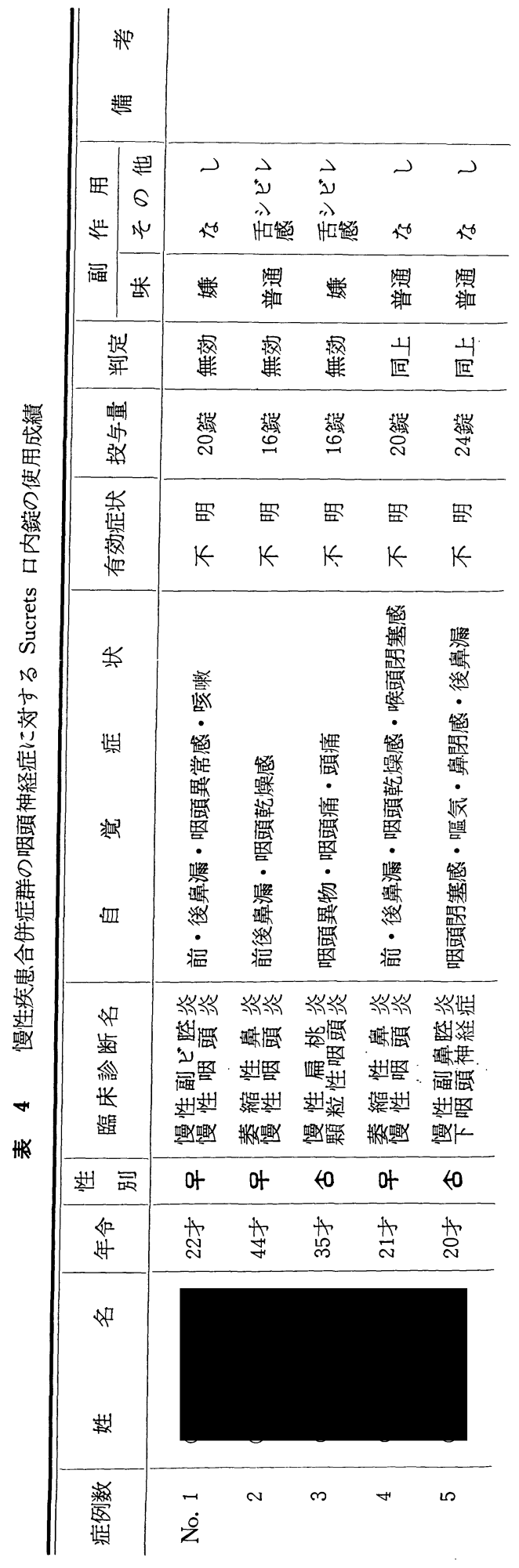

殺菌力がないこと，および萎縮性鼻炎・慢性副鼻腔炎 等の治療㙨序に奏効する作用がないか又はすくないた めと考えられる。

このような投与成績から考えて, 煙草の過度契煙に もとづく咽頭異常感，軽度な咽喉頭カタル等には有効 なものであらうと云える.

\section{b 年 令 差}

もつと有効例数の多かつた第 2 群について40才代と 40 f以下の $2 つ の$ 年令層にわけて有效例数をしらべて みると，40才以上では 9 例中 8 例に有効で $89 \% ， 40$ 才 以下の年令では10例中 3 例で $30 \%$ 有効例をみたことに なる. 性別による差異は男が 6/9 女が 7/10で，それ汪 ぞ著明な差異がなかつた。

この年令差にもとづく有効例数の差異は咽喉頭神経 症状をひきおこしている疾患の程度, 種類にもよるが， その一面，いわゆる癌ノイローゼの好発年令とも云え る年代層の咽頭ノイローゼ29) という精神身体症状が大 きく原因しているとも考えられる'.

c. 副 作 用

Sucrets 口内錠を服用時の舌の知覚鈍麻(シビレ感), 独特な Pepermint の味覚に対する好娧を除けば, Hexylresorcinol そのものによる食慾不振, 発汗, 頭痛, 下痢等の徴候は投与例全例についてみられなかつた。

Sucrets 服用時の知覚鈍麻も正常人では〔表 1〕に 示したように一時間以内に消裉する一時的な副作用で あり，特に服用者の大部分が神経症的自覚症状の持ち 主であるところよりすれば，投与の時期を食後等に限 定すれば，食事に際しての味覚障害には余り影響しな いし，鈍麻作用は副作用として余り問題にしなくてよ いと考える.

上述のごとく，咽唉頭神経症患者のうち，舌根扁桃 肥大, 喉頭蓋軟骨異常, 頸椎異常, 過長茎状突起症, 等の顕著な器質的疾患に基因しない神経症患者のなか には，Sucrets 口内錠の服用で主訴の緩解・消失をみせ たものが，かなりにあるし，単に一時的効果とばかり 考えられない著効症例をみたことは，更に本剤が，た んに搘好の域にとぶまらず，広い医療上の効用を有す るものであると推察できる.

\section{6. むす び}

日本メルク万有製薬株式会社より試用の機会 を得た Sucrets 口内錠を, 咽喉頭部神経症患者 に1日4錠宛食後・食間に服用させて，つぎの ような結果を得た。 
1. 投与者32例中16例 (50\%) に症状の緩解又は消失例を観察した。

2. 有効例16例の大部分は, 顕著な器質的疾患の所見をみない患者で, 特に年令的に40才以上の 患者で効果はよかつた。

3. 奏効機序を検討し, 微量の有効成分 Hexylresorcinol の殺菌・知覚鈍麻作用等の局所薬理作 用の相互作用にもとづくものと推論した。

4. 副作用として想像された食慾不振・発汗・頭痛・下痢等の症状は 投与例全例で観察されなか つた.

（堀口申作教授の御校閲を深謝します）

\title{
參 考 文 献
}

1) O. Korner: Handbuch d. Laryngologie u Rhinologie, Bd II. 321 340. 1899, (Dr. P. Heymann)

2）仁保正次・他：日気食会報，2,6 13, 昭26.

3）仁保正次・他 $\cdot$ 日気食会報，5, 18～22, 昭29.

4) S. Niho et al : Archiv. Otolaryng. Vol 70, 98 $\sim 102,1959$.

5）浜 孝雄・他：日耳鼻，51，2，58，昭23.

6) 神前 穣: 日耳鼻, 51, 166, 昭23.

7）桐谷信雄 : 日耳鼻, 57, 207, 昭 29.

8）大久保 環：日耳鼻，58, 1068, 昭30.

9）池 香子・他: 日耳鼻, 61, 632, 昭33.

10）堀口申作: 耳鼻咽䐅科展望，1，2, 昭34.

11）沖田和巳 : 耳鼻臨床，52，310～312, 昭34.

12）大沢林之助：日医事新報，1943，121, 昭36.

13）安田 等: 日耳鼻, 56, 880, 昭28.

14）日根其二：日耳鼻, 59, 1411, 昭31.
15）緒方 肇：日耳鼻, 62, 858, 昭34.

16）林田秀三郎：日耳鼻，51，90, 昭23.

17）柏戸貞一：耳喉科，26, 745～751, 昭29.

18）川久保淳・他：日耳鼻, 59, 1046, 昭31.

19）大森 守：日耳鼻, 60, 135, 昭32.

20）川久保淳 - 他 : 日耳鼻, 60, 144, 昭32.

21）鈴木 文: 耳喉科, 25, 79, 昭 28.

22）车田哲三郎他：日耳鼻, 60, 294 295, 昭32.

23）西村盛博 - 他：日耳鼻, 60, 84, 311, 昭32.

24）斉藤信三：日耳鼻，60, 1226, 昭32.

25）布村利夫：日耳鼻, 61, 977, 昭33.

26）小林 泰・他: 日耳鼻, 62, 2107, 昭34.

27）豊田交一：日耳鼻，62, 1385, 昭34.

28）中野清幸・他: 日耳鼻, 62, 1670, 昭34.

29）山本常市・他 : 日耳鼻, 63, 213, 昭35.

30）小野真孝：日耳鼻, 63, 778～793, 昭35.

\section{鼓室成断術に対するセフアランチン使用経験}

\author{
山下隆章.上田直 昭*
}

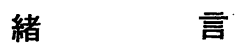

周知の如く，慢性化膿性中耳炎に対する鼓空成形術施行症例の術後経過中において，術創部特に 移植皮膚面の渗出性変化により, 術後治癒過程の遅延あるいは再生鼓膜の穿孔を来す事は, 日常少 なからず経験するところである。

我々は最近セファランチンが耳鼻咽喉科領域において，殊に渗出性中耳炎などの疾患に対して可 なりの治療効果を有するとの諸報告例に接し，今回その分泌抑制作用の効果を期待して，鼓室成形 術後にペニシリンあるいは抗生物質の使用と同時にセフアランチン注射とを併用せるところ，やや

* 広島大学医学部耳鼻咽晚科学教室（主任 : 塚本 寛教授) 